\title{
Influence of the quantity profile of the domestic hot water demand and the energy demand for the heating in a single-family house on the SCOP of the air-to-water heat pump
}

\author{
Kamil Skoneczny ${ }^{1, *}$ \\ ${ }^{1}$ Wrocław University of Science and Technology, Wybrzeże Stanisława Wyspiańskiego 27, \\ 50-370 Wrocław, Poland
}

\begin{abstract}
In the article it was discussed how the energy efficiency of the air-to-water heat pump can change depending on the different ways of the building usage. The author shows that the following factors influence this efficiency: the DHW demand and the demand of the energy for the heating of the building. The article shows that it is very important to take into account the cooperation of both systems, the DHW and the heating. Two models of the SCOP calculations were discussed: in monthly and hourly steps of the calculation. For each model the following assumptions were considered: the different profiles of the domestic hot water demand and the different profiles of the demand for the heating of building.
\end{abstract}

\section{Introduction}

When selecting an air-water heat pump for a single-family house, we are guided primarily by the need for the power necessary to heat the facility. Unfortunately, the tendency to use better and better thermal insulation and more efficient systems results in a reduction of the amount of energy consumed for heating purposes, and also in reducing the required power of the device. When it comes to the domestic hot water (DHW) preparation for residential buildings, the demand for instantaneous power for heating depends on the adopted system solution, water parameters at inlet and outlet of the system. The energy demand depends primarily on the amount of water and the parameters mentioned above. From the engineering point of view, we can recognize that the demand for power is constant over the last years. Therefore, its relation to the demand for heating power increases. Therefore, for a correct selection of the air-to-water heat pumps and for analyzes of the seasonal coefficient of performance (SCOP) the special attention should be paid to the amount of the DHW consumption and the model used for mapping the demand for energy for heating and domestic hot water preparation. The differences between the results of the SCOP analysis for the various assumptions and the different models of the air-to-water heat pump systems were presented in this article.

\footnotetext{
*Corresponding author: 191187@student.pwr.edu.pl
} 


\section{Description of the analysis - the object and the models}

\subsection{The object}

For the purpose of this article a single-family building with a usable area of $174 \mathrm{~m}^{2}$ was adopted. The power demand for the heating purposes (calculated in accordance to the standard EN 12831) was adopted at the level of $6.23 \mathrm{~kW}$. The parameters of the building were show in Table 1. The building is localized in Wrocław (Poland). The use of the natural ventilation system and the underfloor heating is provided in the building.

Table 1. Coefficients of heat transfer through main partitions and building elements along with a comparison with the current regulations [1].

\begin{tabular}{|l|c|c|c|}
\hline \multirow{2}{*}{ Main partitions or building elements } & $\mathbf{U}_{\mathbf{c}}$ & $\mathbf{A}$ & $\mathbf{U}_{\mathbf{c}, \mathbf{m a x}}$ \\
\cline { 2 - 4 } & $\frac{\mathrm{W}}{\mathrm{m}^{2} \cdot \mathrm{K}}$ & \multirow{2}{*}{$\mathrm{m}^{2}$} & $\frac{\mathrm{W}}{\mathrm{m}^{2} \cdot \mathrm{K}}$ \\
\hline External wall & 0.150 & 151.11 & 0.23 \\
\hline External basement wall & 0.222 & 73.89 & 0.23 \\
\hline Roof panel & 0.170 & 41.83 & 0.18 \\
\hline Internal wall & 0.161 & 21.63 & 0.30 \\
\hline Floor on the ground & 0.300 & 41.60 & 0.30 \\
\hline Ceiling under an unheated attic & 0.115 & 44.51 & 0.18 \\
\hline Windows & 0.793 & 21.93 & 1.10 \\
\hline Roof windows & 0.800 & 3.94 & 1.30 \\
\hline Doors in external walls & 1.500 & 2.10 & 1.50 \\
\hline
\end{tabular}

The heat source of the building is an air-to-water heat pump. The heat pump's parameters are described according to the standard EN 14511 by the power Q (kW) and the COP in the characteristic points of the air temperature and the fluid flow temperature. The parameters were show in Tab. 2. The analysis considered the heat pump with an inverter and the heat pump with an on/off power system, both with the same characteristic.

Table 2. The parameters of the heat pump used in the analyzes.

\begin{tabular}{|c|c|c|c|c|c|c|c|c|}
\hline Heat pomp & \multicolumn{4}{|c|}{ P1 } & \multicolumn{4}{c|}{ P2 } \\
\hline & \multicolumn{2}{|c|}{ W 35 } & \multicolumn{2}{c|}{ W 55 } & \multicolumn{2}{c|}{ W 35 } & \multicolumn{2}{c|}{ W 55 } \\
\cline { 2 - 9 } & $Q$ & COP & $Q$ & $C O P$ & $Q$ & $C O P$ & $Q$ & $C O P$ \\
\hline A - 15 & 3.92 & 2.32 & 2.15 & 1.15 & 2.74 & 2.32 & 2.62 & 1.15 \\
\hline A - 7 & 4.21 & 2.79 & 3.33 & 1.67 & 4.04 & 2.79 & 4.25 & 1.74 \\
\hline A - 2 & 2.82 & 3.42 & 5.10 & 2.38 & 5.48 & 3.63 & 6.08 & 2.32 \\
\hline A - 7 & 2.04 & 3.65 & 6.09 & 2.74 & 6.19 & 4.39 & 7.10 & 2.60 \\
\hline A - 20 & 2.42 & 4.39 & 8.65 & 3.57 & 8.04 & 6.99 & 9.75 & 3.57 \\
\hline
\end{tabular}

Figure 1 presents the diagram comparing the power of the heat pumps with the building's heat demand depending on the air temperature. 




Fig. 1. The heat demand and heat pump power depending on the outside temperature.

The underfloor heating system is connected directly into the heat pump. The hot water tank with the heating coil was assumed. The system works with the priority of the hot water preparation. The water capacity of the heating system is enough to omit the heat buffer and there is a possibility of reversing the flow to defrost the evaporator. The hot water tank volume was assumed as 3021 . It contains the heating coil prepared to work with the heat pumps. The other volumes of tanks were analyzed (196 1, 2651,3801$)$, but their influence on the coefficient of performance (COP) and the seasonal coefficient of performance (SCOP) was quite small. The scheme of the installation was show in figure 2.

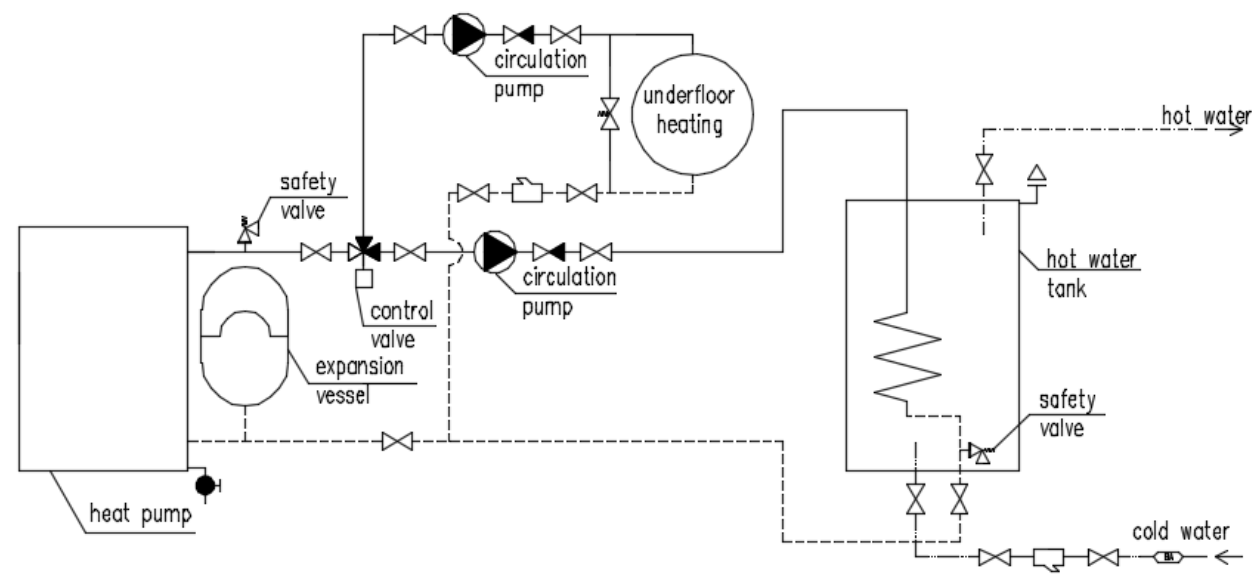

Fig. 2. Scheme of the heat distribution system.

\subsection{The climate profile}

It was decided to adopt the climate data for Wrocław, designated as a typical meteorological and statistical climatic data for the energy calculation of buildings [2]. They have been prepared for the need of energy calculations in construction and can be used in the design and the energy simulations of the buildings. The main parameter for the calculation is the design temperature (in Poland from $-18^{\circ} \mathrm{C}$ to $-24^{\circ} \mathrm{C}$ ) which should be considered for the specific localization and compared with the minimal working temperature of the heat pump. The internal temperature in building was assumed as average temperature of the bathrooms: $24^{\circ} \mathrm{C}$ and the other rooms: $20^{\circ} \mathrm{C}$. This temperature is equal to $20.2^{\circ} \mathrm{C}$. 


\subsection{Domestic hot water demand profile}

While the air temperature changes are not dramatic, the hot water consumption may be characterized as such. Depending on the number of users and their individual preferences, the profiles of daily and even annual water demand are different. What's more, this profile can be changed during the usage of the object - e.g. by another owner, a different number of residents, etc.

The amount of hot water used varies and depends on the residents. Considering the specific use, the amount of water consumed during a day may vary depending on the season, month or even day of the week [5]. The amount of water consumed by one inhabitant seems to be influenced by the number of roommates [5]. It was decided to adopt a fixed daily value of DHW depending on the total number of residents in the facility -100.21 for one resident, 199.81 for 2-3 residents and 3251 for $4-5$ residents.

The next component of the DHW profile is the hourly distribution of the water consumed. It should not come as a surprise that in construction the impact of these individual preferences is the greater the fewer residents reside in the facility. Standard [3] provides different programs for single-family buildings. Tapping programs from 2 to 4 were used, corresponding to the adopted value of DHW. The data was converted to the form of the climate data set - one-hour step (fig. 3).

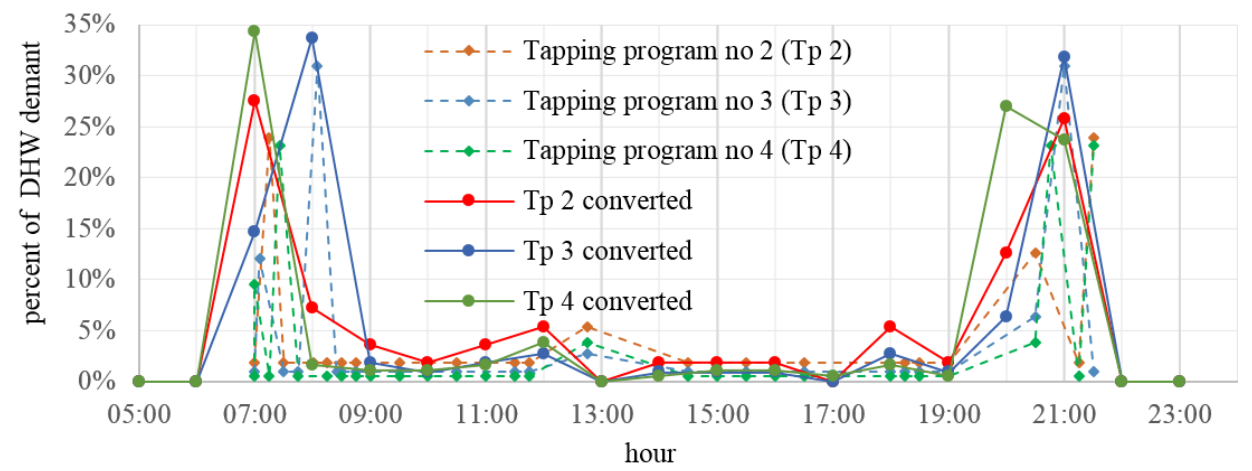

Fig. 3. Conversion of the tapping programs (EN 15316-3: 2006) to the one-hour step.

\subsection{The calculation of the energy demand for DHW}

The method of the calculation of the usable energy which is needed to the DHW preparation according to [3] is based on the hot water consumption $(\mathrm{V})$ and the temperature difference between the cold and warm water $(\Delta \mathrm{T})$.

$$
Q=4.182 \cdot V \cdot \Delta T
$$

The difference $\Delta \mathrm{T}$ is changeable during the year. The reason for this is the year period changes influence the temperature of cold water [5]. Its value depends on its source. Bigger differences are observed for the surface intakes like rivers or lakes and smaller for underground intakes [5]. In this article a simplification was made that the temperature of the cold water is constant and equal to $10^{\circ} \mathrm{C}$. The temperature of the hot water was considered as $50^{\circ} \mathrm{C}$ which is quite a reliable value for the single-family housing usage. Moreover, using hot water pump with a supply temperature equal to $55^{\circ} \mathrm{C}$, it can be achieved. Because of above, it was decided to increase the value of the hot water usage by multiplying values from point 2.3 by the coefficient calculated as:

$$
f=\frac{T_{D H W}-T_{C W}}{T_{D W H}^{*}-T_{C W}^{*}}=\frac{60-10}{50-10}=1.25
$$




\subsection{SCOP models}

There are many models for analysis of the SCOP of air-to-water heat pumps. This article discussed two of them: in the monthly and in the hourly calculating steps. To facilitate the comparison of results, it was decided to use the same climate data for each method.

One of the most important factors that should be taken into account in the energy assessment of the system is the decision whether to take into account the internal heat gains. In the article both solutions were considered. For each model, the heat pump power and electricity consumption was calculated for the following air temperature basing on the $\mathrm{COP}_{55}$ for the hot water production and the $\mathrm{COP}_{35}$ for the heating purposes. The final value of the SCOP for the air-to-water heat pump system is calculated basing on the sum of the energy demand in both systems and the sum of the electricity provided to both systems (to the supply the heat pump's compressor and the electric heater).

\subsubsection{The SCOP model for DHW system}

Model $\mathrm{A}_{(\mathrm{DHW})}$ - The model is based on the average monthly air temperature and the average daily hot water usage.

Model $\mathrm{B}_{(\mathrm{DHW})}-$ The model is based on the hourly air temperature and the hourly hot water profile usage. The first step of the calculations takes into account the water consumed in the hour; this energy goes from the hot water container. In the next steps of the calculation the energy produced by the heat pump in that hour is added to the energy stored in the container (but not over the maximum value taken as full container, the maximum water temperature is taken as $50^{\circ} \mathrm{C}$ ). If the energy resource in the container will be lesser than $62.5 \%$ (which is equivalent of average temperature of water in the tank of $35^{\circ} \mathrm{C}$ ) the electric heater is used to increase the water temperature up to $50^{\circ} \mathrm{C}$. If the water consumption is small and there is a possibility to increase energy level in the container, the heat pump will do it.

\subsubsection{The SCOP model for the heating}

Model $\mathrm{A}_{\text {(HEAT) }}$ - The model is based on the average monthly air temperature and the energy demand calculated based on this temperature and the heat demand of the building.

Model $\mathrm{B}_{\text {(HEAT) }}$ - The model is based on the average monthly air temperature and the heat demand determined based on this temperature and the internal heat gains according to [4].

Model $\mathrm{C}_{(\mathrm{HEAT})}$ - The model is based on the hourly profile of the energy demand for the heating of the building. It is calculated how long the heat pump works to increase the temperature in the tank (for the hot water) and the rest of the time in that hour it can work for heating purposes. It was assumed that the maximum debt of the energy for heating purposes will be equal to $6 \mathrm{kWh}$ (which is the approximation of the situation when the heating system does not work). The energy required to heating is calculated based on the power demand for heating for the actual air temperature. If the debt is bigger, the energy is supported by the electric heater.

Model $\mathrm{D}_{\text {(HEAT) }}$ - The idea of the model is like in $\mathrm{C}_{\text {(HEAT) }}$, but the energy required to the heating is decreased by the heat gain calculated as an average hourly value different for each month. 


\section{Results}

In the article the combinations of the DWH and the heat models taking into account the characteristic of the model were analyzed, like the similar step of the calculations and approach to the internal gains. As a result, four combinations of the models were obtained. For the all analyzed combinations, the influence of the DHW consumption on the energy demand (fig. 8), COP (fig. 4) and SCOP of the system (fig. 5) was shown. Main reasons of the decrease of the COP and SCOP values with the increase of the amount of the heated water is the increase of the share of the energy demand for the DHW preparation in the total energy demand. It is connected with the fact that the COP parameter is lower for higher supply temperatures. The influence is the higher the smaller the demand for the heating of the building is. So, the correct heating demand profile is very important (fig. 7).

For the air-to-water heat pumps with the inverter there is a quite significant difference in energetic efficiency of the system. The difference of that phenomena is visible when we compare the heat pump P1 and P2 - the heat pump P2 has the greater SCOP and COP (fig. 4,5). Taking into account the most realistic heat demand for the DHW preparation and for the heating, it should be possible to provide the results of the simulation matching to the real one.

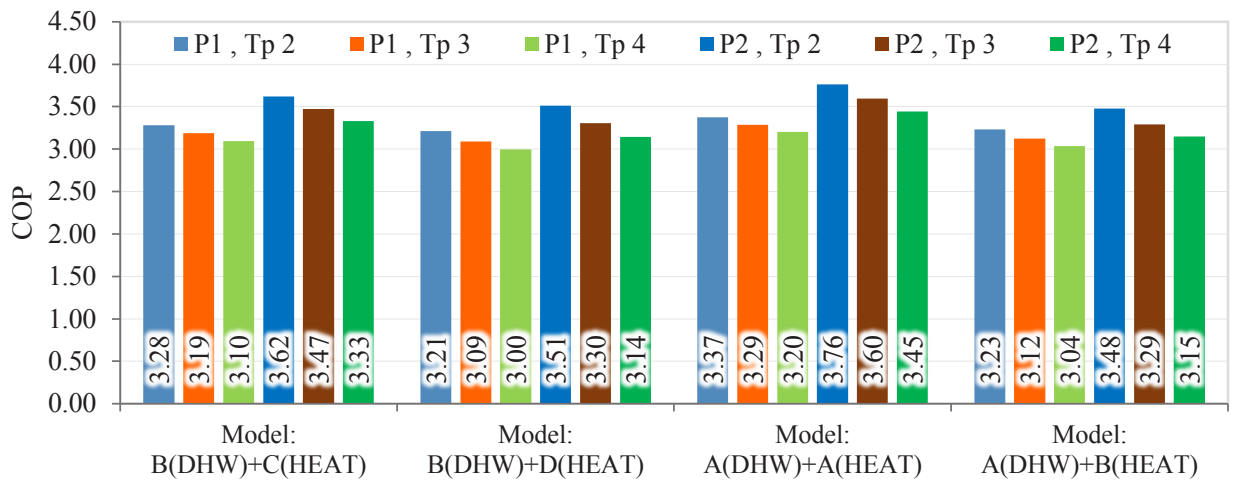

Fig. 4. COP according to models combinations.

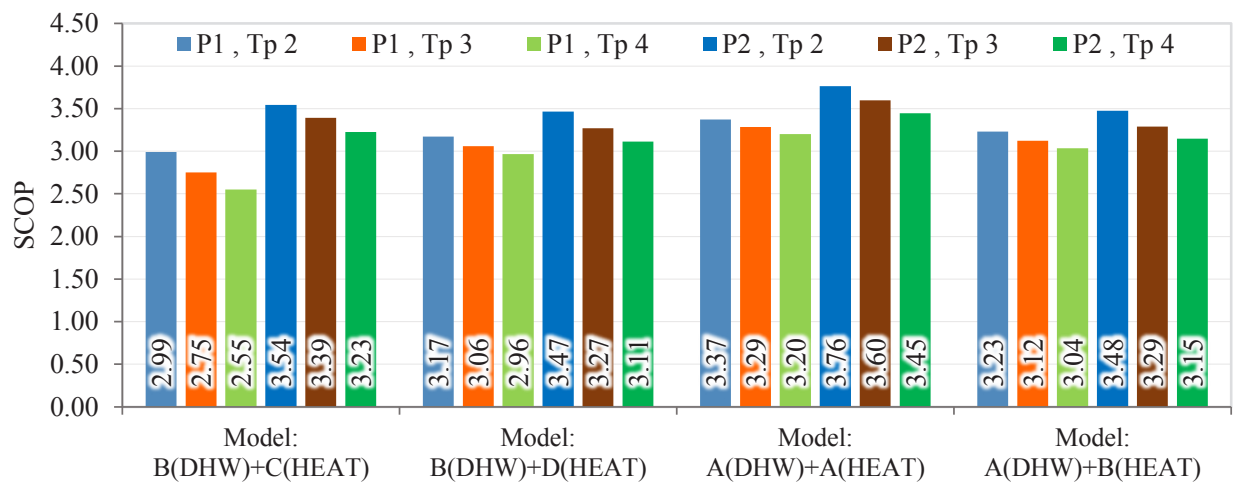

Fig. 5. SCOP according to models combinations. 
Comparing the monthly step of the calculation with the hourly step (columns 1 and 3 on fig. 4,5) we can observe that the shorter step gives the lower values of SCOP and COP. The difference probably is the result of the better parameters for the heat pumps for higher external temperatures and the lack of the energy provided by the electric heater (fig. 6), because the amount of the total energy produced due the heating purposes and for the hot water preparation is almost the same in both models (fig. 7).

Similar results we can get by comparing the monthly step of the calculation with hourly step, but with including internal gains (columns 2 and 4 on fig. 4,5). The difference is a bit smaller but probably it is the result of the lower total energy demand (fig. 7a).



Fig. 6. Percent of the energy provided by the electric heater in the total energy produced by the system according to the models combinations.
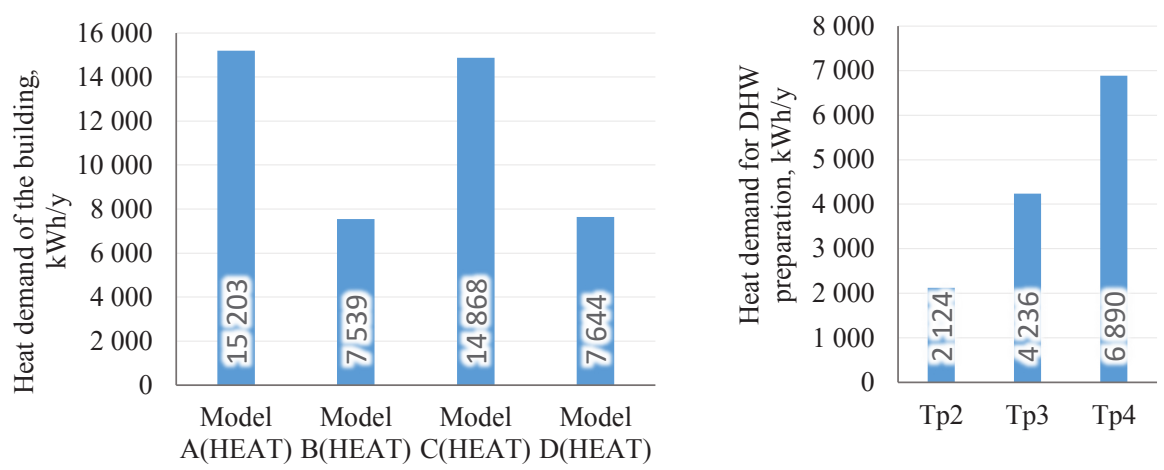

Fig. 7. Total energy a) for heating purposes according to the models combinations, b) for preparing the hot water according to the models combinations.

\section{Conclusions}

The conclusions resulting from the conducted analysis concern only an exemplary singlefamily building and depend on the assumptions made regarding the conditions of use of the object. The work shows how the energy efficiency of the air-to-water heat pump can change for different ways of use of the building. The following factors influence this efficiency: the DHW demand and the demand of the energy for the heating of the building.

The results provided from methods which do not take into account the cooperation of the heating and the hot water preparation (monthly steps of the calculation) give much better results of energy efficiency of the system. However, these results probably are not correct. 
Such analysis can have a significant impact on the cost analyzes for selection of the heat source and also for correct selection of the power of heat pump for the buildings. This is very important to take into account the cooperation of the both systems: the DHW and the heating. The hourly steps calculation gives that possibility.

The difference between the results of the analysis for different assumptions probably have bigger impact for the low-energy buildings. Nowadays, there is a trend to build low-energy and even zero-energy buildings, so there should be more accurate methods of calculation of the energy consumption and energetic efficiency of the air-to-water heat pumps.

\section{References}

1. Rozporządzenie Ministra Infrastruktury z dnia 12 kwietnia 2002 r. w sprawie warunków technicznych, jakim powinny odpowiadać budynki i ich usytuowanie and its subsequent amendments

2. http://mib.gov.pl/2-Wskazniki_emisji_wartosci_opalowe_paliwa.htm

3. EN 15316-3: 2006 Heating systems in buildings - Method for calculation of system energy requirements and system efficiencies - Part 3-1 Domestic hot water systems, characterisation of needs (tapping requirements)

4. Rozporzadzenie Ministra Infrastruktury I rozwoju z dnia 27 lutego 2015 r. w sprawie metodologii wyznaczania charakterystyki energetycznej budynku lub części budynku oraz świadectw charakterystyki energetycznej and its subsequent amendments

5. A. Chmielewska, Modelowanie zapotrzebowania na energie użytkowa do przygotowania cieptej wody $w$ budynkach wielorodzinnych (Raporty Wydziału Inżynierii Środowiska Politechniki Wrocławskiej, 2017) 